\title{
Effect of inoculum type and organic loading on biogas production of sunflower meal and wheat straw
}

\author{
Asad Ayub Rajput ${ }^{*}$ and Zeshan Sheikh
}

\begin{abstract}
Inoculum plays a vital role in providing initial microbial population in anaerobic process. There is unavailability of standard inoculum in the Pakistan and the available inoculum requires pretreatment and preparation before use. Thus, in this study the effect of inoculum type and organic loading $(\mathrm{OL})$ on the biogas yield of sunflower meal and wheat straw was evaluated. For this purpose, lab scale batch experiments were conducted at OL of $2 \mathrm{~g} \mathrm{VS} \mathrm{L}^{-1}$ in $225 \mathrm{~mL}$ glass bottle using digested manure, acclimatized sludge and septic tank sludge as inoculum. The highest biogas yield and volatile solids reduction of $768 \mathrm{NmL} \mathrm{g}{ }^{-1}$ VS and $78 \%$, respectively, were observed from sunflower meal with digested manure. Reactor inoculated with digested manure also showed better buffering capacity in terms of $\mathrm{pH}$. The inoculum selected from first experiment was used to study the effect of $\mathrm{OL}\left(2,6,10\right.$ and $\left.14 \mathrm{~g} \mathrm{VS} \mathrm{L}^{-1}\right)$ on biogas yield. Results showed that biogas yield decreased with the increased in OL. Stability parameters revealed that reactors can be operated safely up to OL of $10 \mathrm{~g}$ VS L ${ }^{-1}$. Biogas production data were modelled by modified Gompertz function.
\end{abstract}

Keywords: Anaerobic digestion, Digested manure, Septic tank sludge, Inoculum, Wheat straw, Sunflower meal

\section{Introduction}

Pakistan is an energy deficient country and facing severe energy crises [1]. To overcome energy crisis, the country is looking for different renewable energy options [2]. On the other hand, Pakistan is an agricultural country and generates huge quantities of biomass. It generates around 69 thousand Mt. of agricultural crop residues per year [3], which can be employed for production of bioenergy. Wheat straw (WS) is an example of such crop residues produced in huge quantities from agricultural fields amounting to approximately 25 thousand Mt. every year [4]. Major portion of this agricultural by-product is consumed by livestock in the country, while rest of the produced WS is burned in the open environment which leads to serious environmental pollution. Sunflower meal (SM) is the byproduct of edible oil industry produced in huge amounts. It is obtained by pressing already extracted oil seeds. Pakistan annually produces 202 $\mathrm{kt}$ of sunflower residue which is considered as a significant biomass resource [5]. This agro-industrial residue is produced in huge quantities and has very limited re-use [6].

\footnotetext{
* Correspondence: asaadrajput@gmail.com

Institute of Environmental Sciences and Engineering, National University of Sciences and Technology, Islamabad 44000, Pakistan
}

Agricultural by-products are thus considered as one of the promising feedstock for anaerobic digestion (AD), a technique used to produce renewable bioenergy. In addition, AD gives several other benefits such as stabilization of organic waste as well as production of digestate that can be used as a soil amendment, and mitigation of greenhouse gas emission. Batch AD of organic waste is a simple way to assess its biogas production potential. Many laboratory scale batch studies have been conducted in the past on the $\mathrm{AD}$ of different organic wastes, and in all of them, inoculum source played a key role in the degree of biodegradation due to differences in microbial consortia [7-9].

Biodegradation rate and lag time of organic waste rely on concentration of microorganisms. Lignocellulosic structure of agricultural and industrial by-product is the main hindrance in their bacterial degradation [10]. Moreover, these by-products, such as WS and SM, cannot be easily digested by microbes, thus external source of anaerobic microorganisms is required to start $A D$ process. An active inoculum can provide extra methane producing microorganisms [11]. Further, a good source of inoculum can enhance anaerobic biodegradability,

(C) The Author(s). 2019 Open Access This article is distributed under the terms of the Creative Commons Attribution 4.0 International License (http://creativecommons.org/licenses/by/4.0/), which permits unrestricted use, distribution, and reproduction in any medium, provided you give appropriate credit to the original author(s) and the source, provide a link to the Creative Commons license, and indicate if changes were made. The Creative Commons Public Domain Dedication waiver (http://creativecommons.org/publicdomain/zero/1.0/) applies to the data made available in this article, unless otherwise stated. 
shorten lag phase and can make process more stable [12]. Digestates from anaerobic project can also provide extra nutrients source during the $\mathrm{AD}$ of agriculture waste. Micronutrient concentration in an inoculum can increase the enzyme activity and biogas yield [13].

Digestates from engineering anaerobic project are thus promising source for these inoculums [14]. Unfortunately, such standard anaerobic inoculum is not available in the study region due to presence of very few wastewater treatment plants, most of which are based on aerobic process. Digested manure and fresh cow dung are two main sources of the inoculums readily available in Pakistan [15]. Due to unavailability of standard inoculum, available inoculum requires pretreatment. Inoculum pretreatment involves steps like dewatering, sieving, pre-incubation and degassing [16]. Pre-incubation of manure or cow dung is performed as it helps in decreasing biogas production from endogenous material of inoculum [17]. The purpose of pre-incubation is to minimize the gas production from inoculum and to maximize gas production from the fed substrate.

Several factors affect the performance and stability of AD process, which include feedstock characteristics, operational conditions and reactor design. The organic loading (OL) is an important design parameter as it indicates the amount of volatile solids (VS) to be fed per unit volume of the digester. The parameter is important because overloading of substrates can cause digester failure in a very short period. Many studies have been conducted about the effect of VS loading or OL on the performance of digester [18-20]. However, the effect of OL of the newer substrates like SM and WS in the presence of available inoculum could produce valuable information which could be useful for optimization of digesters under prevailing conditions of the region.

Non-linear kinetic model fitting is an effective way to predict kinetics of biogas production. Modified Gompertz model is one of the non-linear models used globally to predict biogas production. This model can predict important parameters of biogas production such as biogas production rate and lag phase.

The focus of the study is to assess the effect of inoculum type and OL on the AD of SM and WS. Further, effect of inoculum type and OL on the buffering capacity of digesters has also been studied. In addition, modified Gompertz model was also fitted on biogas production data obtained from the experiments. Results of the study provide vital information about these inoculums where standard source of inoculum is not available.

\section{Materials and methods}

In this study two laboratory scale experiments were conducted under mesophilic conditions. In first experiment, three different types of inoculum including digested manure, septic tank sludge and acclimatized sludge were assessed for their effectiveness to digest SM and WS at OL of $2 \mathrm{~g} \mathrm{VS} \mathrm{L}^{-1}$ in $225 \mathrm{~mL}$ glass bottle and substrate to inoculum ratio of 1 (on weight of VS basis). In second experiment, best inoculum in terms of higher biogas yield from experiment 1 was used to study the effect of different OLs $\left(2,6,10\right.$ and $\left.14 \mathrm{~g} \mathrm{VS} \mathrm{L}^{-1}\right)$ of the two substrates. The detail of materials and methods is given in the following sections.

\section{Inoculums and substrates}

In this study three different inoculums (digested manure, septic tank sludge and acclimatized sludge) were used. Digested manure was collected from local biogas plant near the study area. The acclimatized sludge used in the study was the sludge collected from pilot scale aerobic membrane bioreactor plant of $50 \mathrm{~m}^{3} \mathrm{~d}^{-1}$ capacity treating municipal wastewater, which was acclimatized under mesophilic anaerobic conditions without addition of any substrate. Lastly, septic tank sludge was obtained from septic tank treating municipal wastewater. Further, all the inoculums were prepared according to method described by Rajput et al. [21].

Two different substrates including SM and WS were used in the study. SM was collected from local edible oil extraction plant and WS was collected from local farmer near study area. WS and SM were oven dried at $60^{\circ} \mathrm{C}$ to balance the moisture in both substrates. WS was crushed up to the size of $5 \mathrm{~mm}$ with the help of lab scale crusher and then stored at $4{ }^{\circ} \mathrm{C}$ in a refrigerator until used.

\section{Experimental setup}

In this study $300 \mathrm{~mL}$ glass bottles served as batch reactors with a working volume of $225 \mathrm{~mL}$. Known quantities of substrates and inoculum were added to reactor bottles. Glass bottles were sealed with the help of rubber septum and aluminum crimp cap. The reactors were flushed with nitrogen gas to ensure anaerobic condition. The reactors were placed in an incubator at mesophilic temperature $\left(35^{\circ} \mathrm{C}\right)$ for $45 \mathrm{~d}$. The experiment ended after $45 \mathrm{~d}$ as biogas production plateau was achieved in this time period [22]. Mixing was provided to all the reactors twice a day by manually shaking for $1 \mathrm{~min}$. No external nutrients were added, as the nutrients present in the active inoculum served the purpose. The experiments were conducted at substrate to inoculum (S/I) ratio of 1 to maximize degradation [23]. Biogas was collected in gas collection bags for the determination of methane content.

\section{Experimental conditions}

Experimental conditions for experiment 1

In first experiment, three different inoculums obtained from their respective sources were assessed for $\mathrm{AD}$ of SM and WS. Three sets of reactors viz., SM-I1, SM-I2 
and $\mathrm{SM}-\mathrm{I} 3$ were run for $\mathrm{AD}$ of $\mathrm{SM}$ using digested manure, septic tank sludge and acclimatized sludge as inoculum. Respectively. Similarly, AD of WS inoculated with digested manure, septic tank sludge and acclimatized sludge was performed in another three sets of reactors namely WS-I1, WS-I2 and WS-I3, respectively. For correction of produced biogas, blank reactors consisting of inoculums alone were also run. The experiment was performed in triplicate at a constant $\mathrm{OL}$ of $2 \mathrm{~g} \mathrm{VS} \mathrm{L}^{-1}$, and S/I ratio of 1 (on g VS basis). The required quantities of substrates and inoculums to achieve these conditions were added into batch bottles. The experiment was conducted at mesophilic $\left(35^{\circ} \mathrm{C}\right)$ temperature for 45 $\mathrm{d}$ in triplicate.

\section{Experimental conditions for experiment 2}

In second experiment, the inoculum with the best results in experiment 1 was subjected to $\mathrm{AD}$ of $\mathrm{SM}$ and WS, both at four different OLs of 2, 6, 10 and $14 \mathrm{~g}$ VS $\mathrm{L}^{-1}$. The experiment was conducted at constant $\mathrm{S} / \mathrm{I}$ ratio of 1. Four sets of reactors viz., SM-OL2, SM-OL6, SM-OL10 and SM-OL14 digesting SM were run at OLs of $2,6,10$ and $14 \mathrm{~g} \mathrm{VS} \mathrm{L}^{-1}$, respectively. Similarly, AD of WS was performed at OL of 2, 6, 10 and $14 \mathrm{~g} \mathrm{VS} \mathrm{L}^{-1}$ in another four sets of reactors viz., WS-OL2, WS-OL6, WS-OL10 and WS-OL14, respectively. Known quantities of substrates and inoculums were added in each bottle. All the reactor bottles were incubated at mesophilic temperature $\left(35^{\circ} \mathrm{C}\right)$ for $45 \mathrm{~d}$. The experiment was performed in triplicate.

\section{Analytical parameters}

Daily volume of biogas was measured with the help of gas syringe. For measuring total solids, VS and buffering capacity and rector stability before and after $45 \mathrm{~d}$ of digestion samples were taken to determine $\mathrm{pH}$, total alkalinity (TA) and volatile fatty acids (VFA) according to Standard Methods [24]. $\mathrm{pH}$ of solids like SM and WS was analyzed in 1:5 suspension of biomass to water. For the determination of methane content in biogas, biogas analyzer (Geotech 5000, UK) was used.

VS removal was calculated with the help of Eq. (1).

$$
\text { VS removal }(\%)=\left(\frac{V S(\text { added })-V S(\text { Final })}{V S(\text { added })}\right) * 100
$$

Where,

$\mathrm{VS}$ (added) $=\mathrm{g}$ VS of substrates added in to the reactor at the start of experiment. VS ${ }_{(\text {Final })}=\mathrm{g}$ VS of substrates after $45 \mathrm{~d}$ of digestion.

\section{Statistical analysis}

All the experiments and analysis were performed in triplicate and the average values were presented in tables and figures. Furthermore, analysis of variance was performed to find the significance differences between the results. Principal component analysis (PCA) was performed using SPSS 16 to find the relationship between OLs and parameters. In PCA results F1 and F2 are the principal axes with the percentage of variance and $\mathrm{pHo}$, TAo and VFAo denotes the parameters of SM and $\mathrm{pHi}$, TAi and VFAi related to WS.

\section{Kinetic study}

In this study modified Gompertz model was used for kinetic model fitting of the observed biogas production data. The same kinetic model was used to predict hydrogen production as shown in Eq. (2) [25].

$$
M=P_{b} \times \exp \left\{-\exp \left[\frac{R_{m} \cdot e}{P_{b}}(\lambda-t)+1\right]\right\}
$$

Where $\mathrm{M}$ is the cumulative biogas yield ( $\mathrm{NmL}$ biogas $\mathrm{g}^{-1}$ VS) with respect to AD time $t(d), R_{m}$ is the maximum biogas production rate $\left(\mathrm{NmL}\right.$ biogas $\left.\mathrm{g}^{-1} \mathrm{VS} \mathrm{d}^{-1}\right)$, $\mathrm{P}_{\mathrm{b}}$ is the maximum biogas potential (NmL biogas $\mathrm{g}^{-1}$ VS) at the end of $\mathrm{AD}, \lambda$ is the lag phase time (d) and $\mathrm{e}$ is a Euler's function equal to 2.7183 . The kinetic estimation was performed using the IBM SPSS Statistics 16.

\section{Results and discussion}

Effect of inoculum type on biogas production and solids removal

In first experiment, three different inoculums including digested manure, septic tank sludge and acclimatized sludge were evaluated for AD of SM and WS. Daily biogas yield from $\mathrm{AD}$ of SM and WS is presented in Fig. 1. Digested manure and acclimatized sludge gave better biogas yield as compared to septic tank sludge. Highest daily biogas yield was observed from SM inoculated with digested manure after $20 \mathrm{~d}$ of digestion as shown in Fig. 1. Reactors inoculated with septic tank sludge gave a high daily biogas yield at the beginning, which quickly decreased as the digestion progressed further.

Cumulative biogas yields from reactors SM-I1, SM-I2, SM-I3, WS-I1, WS-I2 and WS-13 were 768, 381, 691, 556, 297 and $397 \mathrm{NmL}$ biogas $\mathrm{g}^{-1} \mathrm{VS}$ respectively as shown in Fig. 1. Highest cumulative biogas yield of 768 NmL biogas $\mathrm{g}^{-1}$ VS was observed for SM inoculated with digested manure as shown in Fig. 1. Methane content in produced biogas from batch reactors inoculated with different inoculums SM-I1, SM-I2, SM-I3, WS-I1, WS-I2 and WS-I3 were 58, 53, 55, 56, 52 and 53\% respectively. Lowest cumulative biogas yield of $297 \mathrm{NmL}$ $\mathrm{g}^{-1}$ VS was observed for WS inoculated with septic tank sludge. SM inoculated with digested manure showed 102 and $11 \%$ higher biogas yield as compared to septic tank 




Fig. 1 Cumulative biogas yield from SM and WS inoculated with different inoculums

sludge and acclimatized sludge. Similarly, WS inoculated with digested manure showed 87 and $40 \%$ higher biogas yield as compare to septic tank sludge and acclimatized sludge. A study conducted on SM using anaerobic sludge as inoculum at $2 \mathrm{~g}$ TS $\mathrm{L}^{-1}$ under mesophilic temperature $\left(35^{\circ} \mathrm{C}\right)$ reported biogas yield of $693 \mathrm{~mL} \mathrm{~g}^{-1}$ TS, which is almost in line with the result of present study [26]. Biogas yield of WS in the present study is higher than another study [27]. Higher biogas yield might be due to inoculum preparation, pre-incubation and degassing [28]. The purpose of pre-incubation and degassing was to prepare various types of inoculum for their subsequent use in the comparative study of biogas production from the substrates. Therefore, the results of pre-incubation and degassing were not included in the present study, rather the results of effect of various types of inoculum prepared through a common method on biogas production from substrates were compared another reason might be the use of a sufficiently low OL in the reactors which resulted in stable operation and hence produced increased volume of biogas. It is noteworthy that the lowest biogas yields from both the substrates were achieved from the reactors inoculated with septic tank sludge, which might be due the accumulation of VFA as shown in Fig. 2b, which in turn might have caused acidification. The reason for accumulation of VFAs might be that the septic tank sludge was partially digested with VFA production as it was taken from septic tank [29].

Based on Fig. 1, it can be concluded that significant differences $(p<0.05)$ in the results of digested manure, septic tank sludge and acclimatized sludge were observed, when used as an inoculum. Higher and steadier biogas yield from WS and SM was observed from the reactors inoculated with digested manure as compared to other inoculums. The results of the study are similar to another study which compared different inoculum sources for the $\mathrm{AD}$ of rice straw and digested manure performed better in terms of higher biogas yield, buffering capacity and nutrients content [30]. Various biological or biochemical reasons have been provided by other researchers for increase in biogas yield due to inoculum. For instance, inoculum affects the anaerobic process by providing initial microbial population which plays a key role in enhancing biogas production [31]. Another reason in enhancing biogas production might be the micro and macro nutrients content of inoculum which is required by anaerobic process [32] Enzymes activity of inoculum in degradation of cellulose and hemicellulose might be another reason for enhancing biogas production [30]. Stable production of VFAs and TA due to inoculum might provide the sufficient buffering capacity to the anaerobic reactor and ultimately affect digestion process [11].

VS reduction is another useful parameter for assessing the effectiveness of AD process. VS removal from WS and SM inoculated with digested manure, septic tank sludge and acclimatized sludge is presented in Fig. 3. VS removal from reactors SM-I1, SM-I2, SM-I3, WS-I1, WS-I2 and WS-13 were 78, 31, 72, 70, 26 and 52\%, respectively. Highest VS reduction of $78 \%$ was observed from SM inoculated with digested manure, while lowest 

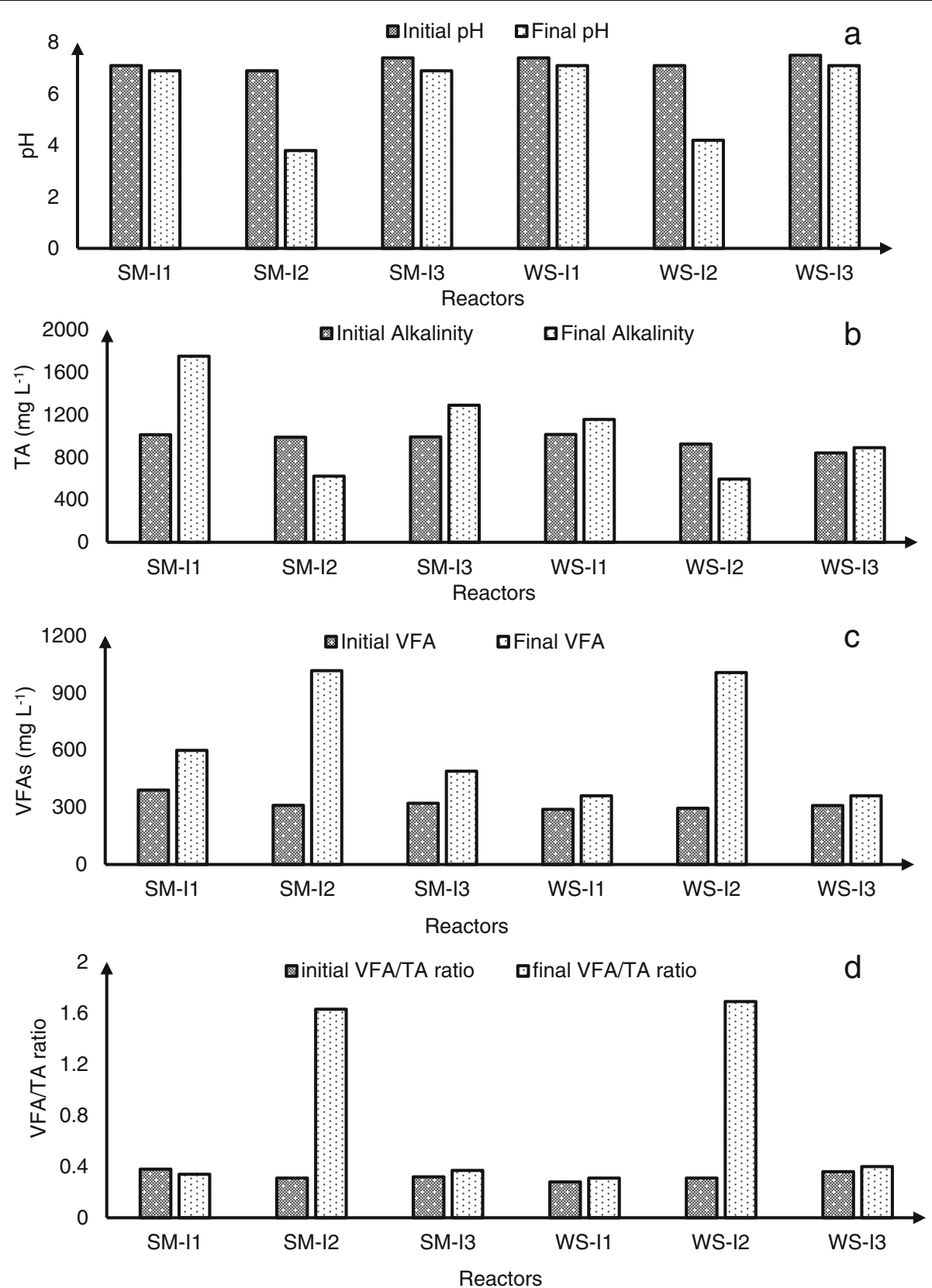

Fig. 2 Buffering capacity and reactor stability parameters (a) pH (b) TA (c) VFAs (d) VFA/TA ratios

VS reduction of $26 \%$ was observed from WS inoculated with septic tank sludge as shown in Fig. 3. Higher VS reduction yielded higher production of biogas as the trend in VS removal was same as biogas yield. A study conducted on the effect of mixing ratio of food waste and rice husk, and substrate to inoculum ratio on biogas production reported similar relationship between biogas production and solids removal [15]. Further, Abudi et al. [33] also supported these results and found similar trend between biogas production and solids removal from AD of rice straw and municipal solid waste.
Effect of inoculum type on buffering capacity and reactor stability

Stability parameters of anaerobic reactor are the environmental variables which affect the harmonic relationship between acid formers and methane formers during AD process. Disturbance of these parameters affects the efficiency of methane formers, which causes the accumulation of acids in the reactor and may lead to digester failure. The environmental factors known to be important in affecting anaerobic digester stability include ammonia concentration, VFA concentration, $\mathrm{pH}$, concentrations of 


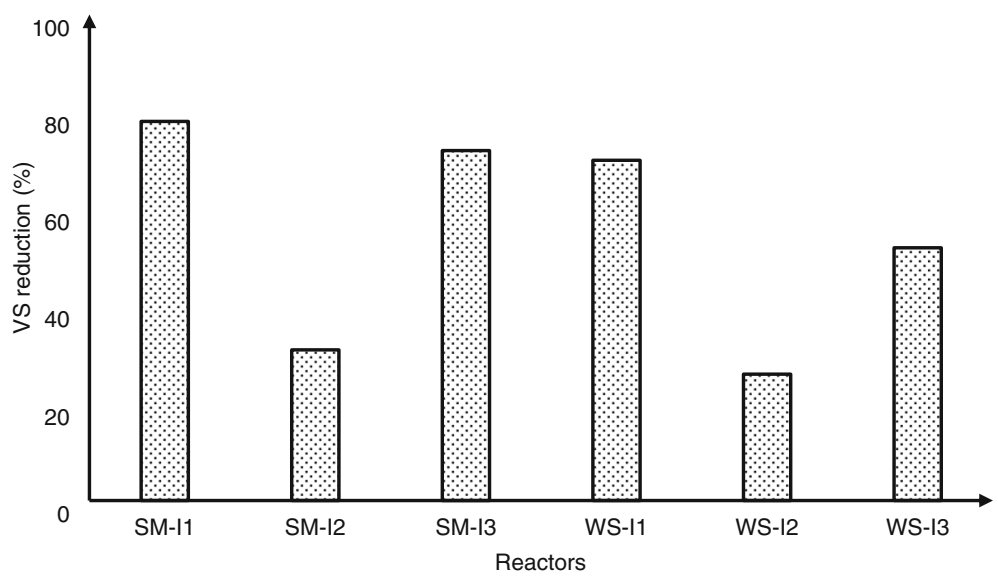

Fig. 3 VS removal from SM and WS inoculated with different inoculums

various cations, sulfide concentration, partial pressure of hydrogen, and the carbon to nitrogen ratio $(\mathrm{C}: \mathrm{N})$ of the feedstocks. Several authors have analyzed AD process in terms of stability for different type of waste by means of monitoring parameters such as $\mathrm{pH}$, TA, VFAs, VFA/TA ratio and biogas production [34, 35].

Initial and final $\mathrm{pH}$ of all the reactors was measured as presented in Fig. 2a. Initial pH for all the reactors were in the range of 6.9-7.5 which was in suitable range for $\mathrm{AD}$. The final $\mathrm{pH}$ of all reactors was in the range of 6.9-7.1 except SM-I2 and WS-I2. Methane producing organisms require an optimal $\mathrm{pH}$ range of $6.5-8.2$ [36], when the $\mathrm{pH}$ value is higher than 8.5 , it has toxic effects on the $\mathrm{AD}$ [37]. The final $\mathrm{pH}$ for the reactors inoculated with septic tank sludge (SM-I2 and WS-I2) was in the range of 3.8-4.2 as shown in Fig. 2a. It dropped to 4.2 for slowly biodegradable substrate of WS and 3.8 for relatively easily biodegradable substrate of SM. The reason for drop in $\mathrm{pH}$ from 7.5 to about 4 in reactors inoculated with septic tank sludge might be the accumulation of VFA as depicted in Fig. $2 \mathrm{~b}$.

Alkalinity is another reliable parameter after $\mathrm{pH}$ to assess the imbalance of digesters. In this study, the only source of external alkalinity was inoculums. No extra chemical alkalinity was added in the reactors. Initial and final alkalinity of digesters is shown in Fig. 2b. Reactors inoculated with digested manure showed higher initial and final alkalinity. The degradation of protein present in the waste releases $\mathrm{NH}_{3}$, which reacts with $\mathrm{CO}_{2}$ and $\mathrm{H}_{2} \mathrm{O}$ forming $\mathrm{NH}_{4} \mathrm{HCO}_{3}$ alkalinity. The degradation of salt of fatty acids may produce some alkalinity as $\mathrm{NaHCO}_{3}$. Sulfate and sulfite reduction also generate alkalinity. Due to higher initial and final alkalinity, biogas yield was higher in digesters inoculated with digested manure for digestion of both the substrates. Initial and final VFAs concentrations in all the reactors are shown in Fig. 2c. It has been reported that VFAs concentration higher than $5000 \mathrm{mg} \mathrm{L}^{-1}$ may inhibit $\mathrm{AD}$ [38].
Another important parameter required in monitoring of digester stability is VFA/TA ratio. Initial VFA/TA ratio of reactors were SM-I1, SM-I2, SM-I3, WS-I1, WS-I2 and WS-I3 0.38, 0.31, 0.32, 0.28, 0.31 and 0.36, whereas final VFA/TA ratio were 0.33, 1.6, 0.37, 0.31, 1.6 and 0.4 , respectively. All the reactors inoculated with digested manure and acclimatized sludge had VFA/TA ratio in the range of 0.31 to 0.40 except the reactors inoculated with septic tank sludge in which it was higher than this range. It might be due to the rapid production of VFAs as shown in Fig. 2d. According to Kafle and Kim [39], VFAs/TA ratio should be less than 0.4 for a heathy anaerobic digester. It can be concluded that digesters inoculated with digested manure and acclimatized sludge showed desirable range of VFA/TA ratio with both the substrates indicating better stability and buffering capacity of the anaerobic process.

\section{Effect of OLs on biogas production of SM and WS}

In second experiment, the effect of four different OLs 2, 6,10 and $14 \mathrm{~g} \mathrm{VS} \mathrm{L}^{-1}$ on biogas yield of WS and SM was studied with the best selected inoculum (i.e., digested manure) from experiment 1 . The results have been presented in Fig. 4. Cumulative biogas yield from reactors SM-OL2, SM-OL6, SM-OL10, SM-OL14, WS-OL2, WS-OL6, WS-OL10, WS-OL14 were 768, 636, 518, 226, 509, 477, 434 and $198 \mathrm{NmL}$ biogas $\mathrm{g}^{-1}$ VS, respectively. The highest cumulative biogas yield of $768 \mathrm{NmL}$ biogas $\mathrm{g}^{-1} \mathrm{VS}$ was achieved from SM at OL of $2 \mathrm{~g} \mathrm{VS} \mathrm{L}^{-1}$ and the lowest biogas yield of $198 \mathrm{NmL}$ biogas $\mathrm{g}^{-1}$ VS was observed from WS at $14 \mathrm{~g} \mathrm{VS} \mathrm{L}^{-1}$ as shown in Fig. 4. As shown in the results, with increase in OL, there was almost a proportional decrease in biogas yield. Overall, the biogas yield of SM was higher than that of WS. SM at OL of $2 \mathrm{~g} \mathrm{VS} \mathrm{L}^{-1}$ gave 21,48 and $240 \%$ higher biogas yield as compared to that at OLs of 6,10 and $14 \mathrm{~g} \mathrm{VS} \mathrm{L}^{-1}$, respectively. Similarly, 


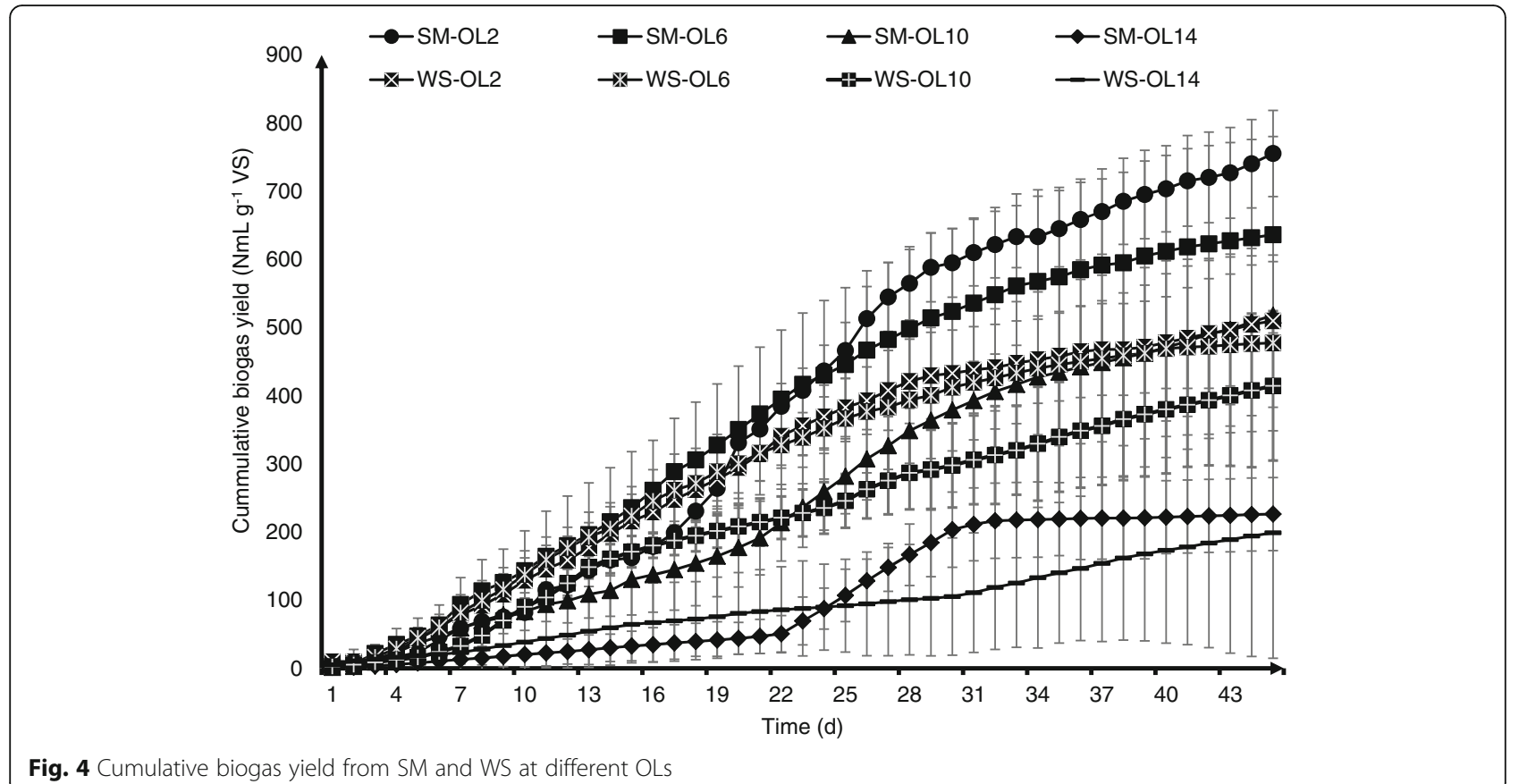

Fig. 4 Cumulative biogas yield from SM and WS at different OLs

WS at OL of $2 \mathrm{~g} \mathrm{VS} \mathrm{L}^{-1}$ produced 7, 17 and $157 \%$ more biogas as compared to that at OL of 6,10 and $14 \mathrm{~g}$ VS $\mathrm{L}^{-1}$, respectively. Significant differences $(p<0.05)$ were noted between different OLs tested in the study in terms of biogas production.

In this study strong relationship between OL and biogas yield was observed. As the OL increased biogas yield tended to decrease. A study conducted on the effect of feeding frequency and OL on biogas yield of rice straw reported results in line with the present study [40]. Further, Elsayed et al. [27] studied the effect of different VS loadings on the batch mesophilic co-digestion of WS and primary sludge and observed a decreased biogas yield at increased OL which is also in line with the present study.

Biogas yield from SM and WS decreased 3.3 and 2.6 times respectively when the OL was increased from 2 to $14 \mathrm{~g} \mathrm{VS} \mathrm{L}^{-1}$. This might be because of low OL of $2 \mathrm{~g} \mathrm{VS}$ $\mathrm{L}^{-1}$ which provided suitable conditions for anaerobic microorganisms to grow and reproduce and convert the carbon content of the SM and WS to biogas through the anaerobic process. This study presented the results of batch experiment. However, semi-continuous operation is the goal for most $\mathrm{AD}$ processes. In semi-continuous the inoculum is added only at the start of the process, the nutrients provided by the inoculum are diluted with time due to addition of feedstock lacking required ratio of nutrients, which may adversely affect the process. The issue can be overcome by using feedstock of suitable nutrient ratio [41]. Furthermore, the present batch study used OLs of 2, 6, 10 and $14 \mathrm{~g}$ VS $\mathrm{L}^{-1}$, however, in case of semi-continuous operation, a relatively more important term of organic loading rate is used. In semicontinuous mode the digesters are normally operated in the range of $1-5$ and $5-15 \mathrm{~g} \mathrm{VS} \mathrm{L}^{-1} \mathrm{~d}^{-1}$ in the case of low-solids and high-solids digestion respectively.

VFA concentrations of both the substrates inoculated with digested manure showed sufficient values as shown in Table 1, which led to the biogas production. The PCA revealed that VFA concentrations increased with increase in OL for both the substrates and observed a very high correlation as shown in Fig. 5. Biogas yield decreased with increase in organic loads for both the substrates that might be due to rapid production of VFAs which could not be consumed as quickly as produced and might have resulted in lower biogas production. Further, strong relationship between VFAs, $\mathrm{pH}$, TA and OL was observed as shown in Table 1. PCA further

Table 1 Effect of OLs on stability parameters of digesters

\begin{tabular}{|c|c|c|c|c|c|c|c|c|}
\hline \multirow[t]{2}{*}{ Reactors } & \multicolumn{2}{|l|}{$\mathrm{pH}$} & \multicolumn{2}{|c|}{ VFA $\left(\mathrm{mg} \mathrm{L}^{-1}\right)$} & \multicolumn{2}{|c|}{ TA $\left(\mathrm{mg} \mathrm{L}^{-1}\right)$} & \multicolumn{2}{|c|}{ VFA/TA } \\
\hline & Initial & $\overline{\text { Final }}$ & Initial & $\overline{\text { Final }}$ & Initial & $\overline{\text { Final }}$ & Initial & $\overline{\text { Final }}$ \\
\hline$\overline{S M-O L 2}$ & 7.1 & 6.9 & 390 & 598 & 1011 & 1750 & 0.38 & 0.34 \\
\hline SM-OL6 & 7.3 & 6.8 & 370 & 688 & 1014 & 2128 & 0.36 & 0.32 \\
\hline SM-OL10 & 7.3 & 6.2 & 331 & 1422 & 1141 & 3610 & 0.29 & 0.39 \\
\hline SM-OL14 & 7.2 & 3.9 & 389 & 2150 & 1112 & 1924 & 0.34 & 1.11 \\
\hline WS-OL2 & 7.4 & 7.1 & 289 & 360 & 1014 & 1155 & 0.28 & 0.31 \\
\hline WS-OL6 & 7.2 & 6.9 & 280 & 712 & 1014 & 1955 & 0.27 & 0.36 \\
\hline WS-OL10 & 7.4 & 6.3 & 261 & 958 & 1024 & 2405 & 0.25 & 0.39 \\
\hline WS-OL14 & 7.3 & 4.6 & 270 & 2055 & 988 & 1611 & 0.27 & 1.27 \\
\hline
\end{tabular}




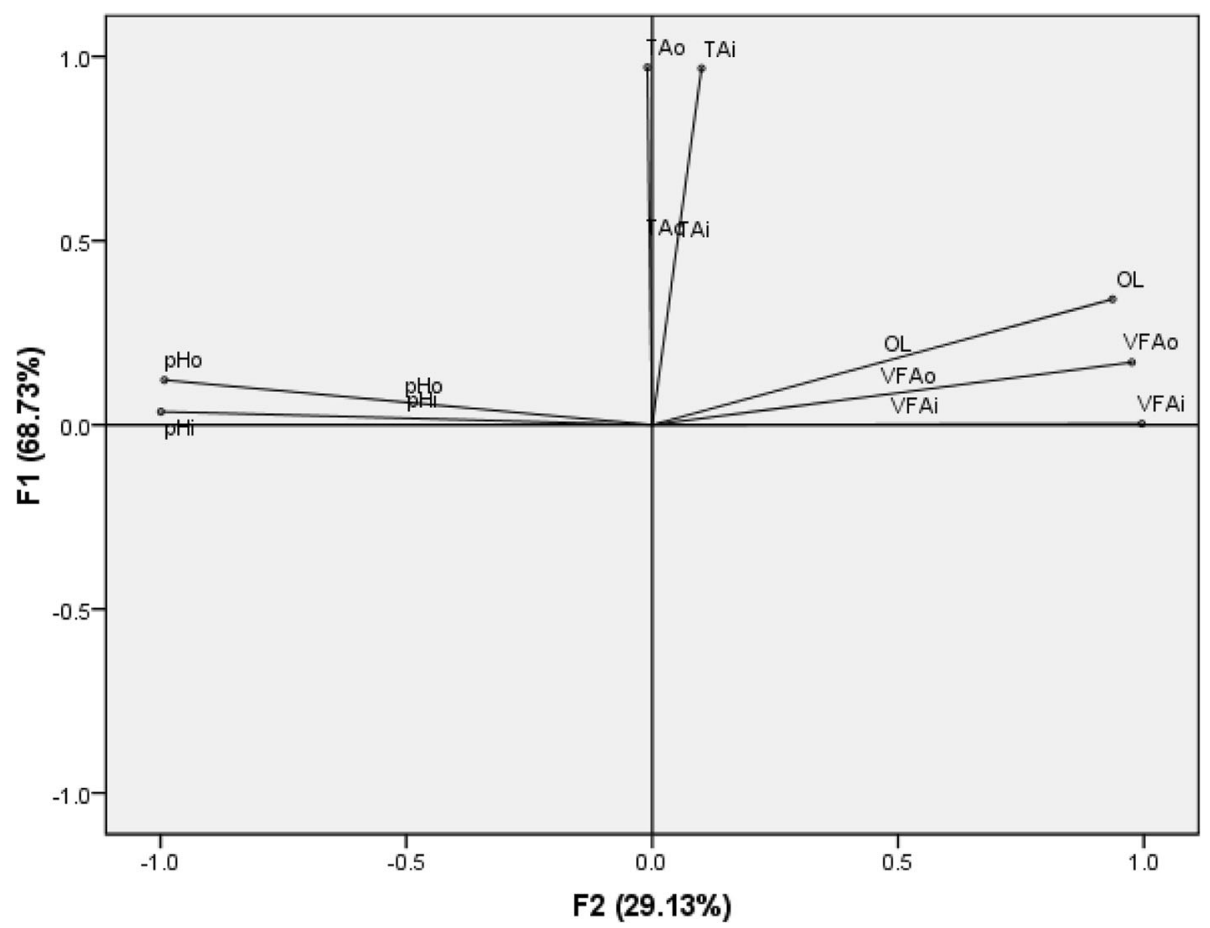

Fig. 5 PCA results of OLs and process parameters

revealed that reactors with high OL showed decrease in $\mathrm{pH}$ and increase in VFAs concentration which ultimately affected the biogas yield as shown in Fig. 5. Reactors fed with SM and WS at OLs higher than $10 \mathrm{~g}$ VS $\mathrm{L}^{-1}$ showed a decrease in biogas yield due to an increased VFA/TA ratio as shown in Table 1. VFA/TA ratio is a very important parameter in assessing the stability of AD process. In this study, VFA/TA ratio obtained after digestion was in the range of 0.31 to 0.39 at OL of 2 to $10 \mathrm{~g} \mathrm{VS} \mathrm{L}^{-1}$, however, it increased to 1.11 and 1.27 at OL of $14 \mathrm{~g} \mathrm{VS} \mathrm{L}^{-1}$ for SM and WS digesters, respectively. A study suggested that VFA/TA ratio should be less than 0.4 for successful commencement of AD [39]. Reactors digesting both the substrates at OL equal and lesser than $10 \mathrm{~g} \mathrm{VS} \mathrm{L}^{-1}$ exhibited a better buffering capacity as shown in Table 1 . AD of WS and SM was found unfeasible at an $\mathrm{OL}$ higher than $10 \mathrm{~g} \mathrm{VS} \mathrm{L}^{-1}$ under prevailing set of experimental conditions. Thus, a suitable OL should be chosen for optimizing the AD process [42]. Lower biogas yields were observed at higher OL due the rapid production of VFAs which might have caused acidification and resulted in lower biogas production [43].

\section{Kinetic study}

The results of kinetic study about the effect of inoculum type and OL on biogas production by using modified Gompertz model are presented in Table 2. In the first part of the study, $R^{2}$ values for various inoculum types fell in the range of 0.974-0.999. Moreover, the biogas production values estimated by the model for the reactors inoculated with digested manure were fairly high as compared to other reactors. Further, it is important to note that septic tank sludge inoculated reactors showed very short lag phase time as compared to other reactors as shown in Table 2. This may be attributed to the inherent anaerobic and pre-acclimatized nature of septic tank sludge due to prevailing conditions of septic tank.

Table 2 Kinetics parameters of modified Gompertz model for various inoculum type and $\mathrm{OL}$

\begin{tabular}{lllll}
\hline Conditions & $R_{\mathrm{m}}\left(\mathrm{mL} \mathrm{g}^{-1} \mathrm{VS} \mathrm{d}^{-1}\right)$ & $\mathrm{P}_{\mathrm{b}}\left(\mathrm{mL} \mathrm{g}^{-1} \mathrm{VS}\right)$ & $\lambda(\mathrm{d})$ & $\mathrm{R}^{2}$ \\
\hline SM-I1 & 33.3 & 735 & 9.97 & 0.994 \\
SM-I2 & 28.9 & 381 & 2.77 & 0.989 \\
SM-I3 & 40.6 & 687 & 6.81 & 0.995 \\
WS-I1 & 21.0 & 573 & 2.38 & 0.998 \\
WS-I2 & 15.5 & 295 & 0.93 & 0.974 \\
WS-I3 & 18.1 & 391 & 2.87 & 0.999 \\
SM-OL2 & 31.6 & 720 & 9.44 & 0.993 \\
SM-OL6 & 24.4 & 610 & 4.86 & 0.997 \\
SM-OL10 & 18.4 & 478 & 8.33 & 0.983 \\
SM-OL14 & 18.7 & 224 & 18.38 & 0.970 \\
WS-OL2 & 19.6 & 485 & 4.0 & 0.998 \\
WS-OL6 & 19.4 & 464 & 3.43 & 0.997 \\
WS-OL10 & 13.2 & 383 & 3.91 & 0.985 \\
WS-OL14 & 5.0 & 168 & 3.86 & 0.952 \\
\hline
\end{tabular}


Valencia et al. [44] treated septic tank sludge by its co-digestion with municipal solid waste in bioreactor landfill simulator and reported that septic tank sludge exhibited a $200 \mathrm{~d}$ shorter lag-phase as compared to the $350 \mathrm{~d}$ required by the control landfill simulator. In second part of the study, $\mathrm{R}^{2}$ values for different OLs were in the range of $0.952-0.998$. Reactors SM-OL2 having $\mathrm{SM}$ and WS-OL2 with WS both at OLs of $2 \mathrm{~g} \mathrm{VS} / \mathrm{L}$ showed the highest biogas production rate $\left(\mathrm{R}_{\mathrm{m}}\right)$ as estimated by the model. Reactor SM-OL14 digesting SM at the highest $\mathrm{OL}$ of $14 \mathrm{~g} \mathrm{VS} \mathrm{L}^{-1}$ showed the longest lag phase time as compared to other reactors. Overall, successful kinetic model fitting was performed, and biogas production data was reproduced by using modified Gompertz model.

\section{Conclusions}

Significant differences in performance of the reactors inoculated with different inoculums were noticed in terms of biogas yield, buffering capacity and VS removal. The performance of digested manure was the best, followed by acclimatized sludge and septic tank sludge. Digested manure showed the highest biogas yield, buffering capacity and solids removal. Biogas yield of both the substrates were the lowest when inoculated with septic tank sludge, however, the lag time with this inoculum was the shortest. In second experiment, the highest biogas yield from both substrates was observed at OL of $2 \mathrm{~g} \mathrm{VS} \mathrm{L}^{-1}$. Biogas yield decreased as the OL increased. Based on the results of stability parameters, it can be concluded that reactors can be operated safely at OL of up to $10 \mathrm{~g}$ VS $\mathrm{L}^{-1}$. Biogas yield data of both the experiments was reproduced by modified Gompertz model with $\mathrm{R}^{2}$ values in the range of 0.95 to 0.99 .

\section{Acknowledgements}

Authors are thankful to National University of Sciences and Technology (NUST), H-12, Islamabad for providing Lab facilities.

\section{Author Contributions}

Both authors read and approved the final manuscript.

\section{Publisher's Note}

Springer Nature remains neutral with regard to jurisdictional claims in published maps and institutional affiliations.

\section{Competing interests}

The authors declare that they have no competing interest.

Received: 3 June 2018 Accepted: 9 November 2018

Published online: 19 March 2019

\section{References}

1. Muneer T, Asif M. Prospects for secure and sustainable electricity supply for Pakistan. Renew Sust Energ Rev. 2007;11:654-71.

2. Shaikh F, Ji Q, Fan Y. The diagnosis of an electricity crisis and alternative energy development in Pakistan. Renew Sust Energ Rev. 2015;52:1172-85.

3. Raheem A, Hassan MY, Shakoor R. Bioenergy from anaerobic digestion in Pakistan: potential, development and prospects. Renew Sust Energ Rev. 2016:59:264-75.
4. Arshadullah M, Ali A, Hyder SI, Khan AM. Effect of wheat residue incorporation along with $\mathrm{N}$ starter dose on rice yield and soil health under saline sodic soil. J Anim Plant Sci. 2012;22:753-7.

5. Saeed MA, Irshad A, Sattar H, Andrews GE, Phylaktou HN, Gibbs BM. Agricultural waste biomass energy potential in Pakistan. In: International Bioenergy Exhibition and Asian Bioenergy Conference. Shanghai; 2015 Oct 21-23.

6. Raposo F, Borja R, Martín MA, Martin A, de la Rubia MA, Rincon B. Influence of inoculum-substrate ratio on the anaerobic digestion of sunflower oil cake in batch mode: process stability and kinetic evaluation. Chem Eng J. 2009; 149:70-7.

7. Nieto PP, Hidalgo D, Irusta R, Kraut D. Biochemical methane potential (BMP) of agro-food wastes from the cider region (Spain). Water Sci Technol. 2012; 66:1842-8.

8. Xie S, Lawlor PG, Frost JP, Hu Z, Zhan X. Effect of pig manure to grass silage ratio on methane production in batch anaerobic co-digestion of concentrated pig manure and grass silage. Bioresour Technol. 2011;102:5728-33.

9. Ho JH, Sung SW. Methanogenic activities in anaerobic membrane bioreactors (AnMBR) treating synthetic municipal wastewater. Bioresour Technol. 2010;101:2191-6.

10. Himmel ME, Ding SY, Johnson DK, Adney WS, Nimlos MR, Brady JW, et al. Biomass recalcitrance: engineering plants and enzymes for biofuels production. Science. 2007;315:804-7.

11. Cordoba V, Fernandez M, Santalla E. The effect of different inoculums on anaerobic digestion of swine wastewater. J Environ Chem Eng. 2016;4:115-22.

12. Quintero M, Castro L, Ortiz C, Guzmán C, Escalante H. Enhancement of starting up anaerobic digestion of lignocellulosic substrate: fique's bagasse as an example. Bioresour Technol. 2012;108:8-13.

13. Zhang L, Lee YW, Jahng D. Anaerobic co-digestion of food waste and piggery wastewater: focusing on the role of trace elements. Bioresour Technol. 2011;102:5048-59.

14. Elbeshbishy E, Nakhla G, Hafez H. Biochemical methane potential (BMP) of food waste and primary sludge: influence of inoculum pre-incubation and inoculum source. Bioresour Technol. 2012;110:18-25.

15. Haider MR, Zeshan YS, Malik RN, Visvanathan C. Effect of mixing ratio of food waste and rice husk co-digestion and substrate to inoculum ratio on biogas production. Bioresour Technol. 2015;190:451-7.

16. Wang B, Stromberg S, Nges IA, Nistor M, Liu J. Impacts of inoculum pretreatments on enzyme activity and biochemical methane potential. J Biosci Bioeng. 2016;121:557-60.

17. Liu T, Sun L, Muller B, Schnurer A. Importance of inoculum source and initial community structure for biogas production from agricultural substrates. Bioresour Technol. 2017;245:768-77.

18. Beevi BS, Jose PP, Madhu G. Effect of total solid concentration on anaerobic digestion of the organic fraction of municipal solid waste. Int J Sci Res Publ. 2013;3:1-5.

19. Yavini TD, Chia Al, John A. Evaluation of the effect of total solids concentration on biogas yields of agricultural wastes. Int Res J Environ Sci. 2014;3:70-5.

20. Tanimu MI, Ghazi TIM, Harun MR, Idris A. Effect of feed loading on biogas methane production in batch mesophilic anaerobic digesters treating food waste. Int J Chem Environ Eng. 2014;5:39-44.

21. Rajput AA, Zeshan VC. Effect of thermal pretreatment on chemical composition, physical structure and biogas production kinetics of wheat straw. J Environ Manag. 2018;221:45-52.

22. Godbout S, Verma M, Larouche JP, Potvin L, Chapman AM, Lemay SP, et al. Methane production potential (B0) of swine and cattle manures - a Canadian perspective. Environ Technol. 2010;31:1371-9.

23. Labatut RA, Angenent LT, Scott NR. Biochemical methane potential and biodegradability of complex organic substrates. Bioresour Technol. 2011;102: 2255-64.

24. APHA. Standard methods for the examination of water and wastewater. 21st ed. Washington, DC: American Public Health Association; 2005.

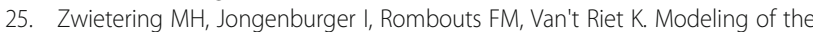
bacterial growth curve. Appl Environ Microb. 1990;56:1875-81.

26. Antonopoulou G, Stamatelatou K, Lyberatos G. Exploitation of rapeseed and sunflower residues for methane generation through anaerobic digestion: the effect of pretreatment. Chem Engineer Trans. 2010;20:253-8.

27. Elsayed M, Andres Y, Blel W, Gad A, Ahmed A. Effect of VS organic loads and buckwheat husk on methane production by anaerobic co-digestion of primary sludge and wheat straw. Energ Convers Manage. 2016;117:538-47. 
28. Raposo F, De la Rubia M, Fernandez-Cegri V, Borja R. Anaerobic digestion of solid organic substrates in batch mode: an overview relating to methane yields and experimental procedures. Renew Sust Energ Rev. 2012;16:861-77.

29. Chatterjee P, Ghangrekar MM, Rao S. Biogas production from partially digested septic tank sludge and its kinetics. Waste Biomass Valori. 2017:1-12.

30. Gu Y, Chen XH, Liu ZG, Zhou XF, Zhang YL. Effect of inoculum sources on the anaerobic digestion of rice straw. Bioresour Technol. 2014;158:149-55.

31. Ventorino V, Romano I, Pagliano G, Robertiello A, Pepe O. Pre-treatment and inoculum affect the microbial community structure and enhance the biogas reactor performance in a pilot-scale biodigestion of municipal solid waste. Waste Manag. 2018;73:69-77.

32. Parra-Orobio BA, Donoso-Bravo A, Ruiz-Sanchez JC, Valencia-Molina KJ, Torres-Lozada P. Effect of inoculum on the anaerobic digestion of food waste accounting for the concentration of trace elements. Waste Manag. 2018;71:342-9.

33. Abudi ZN, Hu ZQ, Sun N, Xiao B, Rajaa N, Liu CX, et al. Batch anaerobic codigestion of OFMSW (organic fraction of municipal solid waste), TWAS (thickened waste activated sludge) and RS (rice straw): influence of TWAS and RS pretreatment and mixing ratio. Energy. 2016;107:131-40.

34. Bjornsson L, Murto M, Mattiasson B. Evaluation of parameters for monitoring an anaerobic co-digestion process. Appl Microbiol Biot. 2000;54:844-9.

35. Nielsen HB, Uellendahl H, Ahring BK. Regulation and optimization of the biogas process: propionate as a key parameter. Biomass Bioenergy. 2007;31: $820-30$

36. Lee DH, Behera SK, Kim JW, Park HS. Methane production potential of leachate generated from Korean food waste recycling facilities: a lab-scale study. Waste Manag. 2009;29:876-82.

37. Chandra R, Takeuchi $H$, Hasegawa T. Methane production from lignocellulosic agricultural crop wastes: a review in context to second generation of biofuel production. Renew Sust Energ Rev. 2012;16:1462-76

38. Dai XH, Duan NN, Dong B, Dai LL. High-solids anaerobic co-digestion of sewage sludge and food waste in comparison with mono digestions: stability and performance. Waste Manag. 2013;33:308-16.

39. Kafle GK, Kim SH. Anaerobic treatment of apple waste with swine manure for biogas production: batch and continuous operation. Appl Energy. 2013; 103:61-72.

40. Zealand AM, Roskilly AP, Graham DW. Effect of feeding frequency and organic loading rate on biomethane production in the anaerobic digestion of rice straw. Appl Energ. 2017:207:156-65.

41. Moller K, Muller T. Effects of anaerobic digestion on digestate nutrient availability and crop growth: a review. Eng Life Sci. 2012;12:242-57.

42. Montingelli ME, Tedesco S, Olabi AG. Biogas production from algal biomass: a review. Renew Sust Energ Rev. 2015;43:961-72.

43. Sun MT, Fan XL, Zhao XX, Fu SF, He S, Manasa MRK, et al. Effects of organic loading rate on biogas production from macroalgae: performance and microbial community structure. Bioresour Technol. 2017;235:292-300.

44. Valencia R, den Hamer D, Komboi J, Lubberding HJ, Gijzen HJ. Alternative treatment for septic tank sludge: co-digestion with municipal solid waste in bioreactor landfill simulators. J Environ Manag. 2009;90:940-5.

Ready to submit your research? Choose BMC and benefit from:

- fast, convenient online submission

- thorough peer review by experienced researchers in your field

- rapid publication on acceptance

- support for research data, including large and complex data types

- gold Open Access which fosters wider collaboration and increased citations

- maximum visibility for your research: over $100 \mathrm{M}$ website views per year

At BMC, research is always in progress.

Learn more biomedcentral.com/submissions 